\title{
Gender inequalities in external cause mortality in Brazil, 2010
}

\author{
Erly Catarina de Moura ${ }^{1}$ \\ Romeu Gomes ${ }^{1}$ \\ Marcia Thereza Couto Falcão ${ }^{2}$ \\ Eduardo Schwarz ${ }^{3}$ \\ Alice Cristina Medeiros das Neves ${ }^{4}$ \\ Wallace Santos ${ }^{4}$
}

\footnotetext{
${ }^{1}$ Instituto Fernandes Figueira, Fiocruz. Av. Rui Barbosa 716, Flamengo. 22250-020 Rio de Janeiro RJ Brasil.erlycm@usp.br ${ }^{2}$ Departamento de Medicina Preventiva, Universidade de São Paulo.

${ }^{3}$ Departamento de Ações Programáticas e Estratégicas, Secretaria de Atenção à Saúde, Ministério da Saúde.

${ }^{4}$ Programa de PósGraduação em Saúde Coletiva, Universidade de Brasília.
}

\begin{abstract}
Objective: To estimate mortality rate by external causes in Brazil. Methods: Mortality national 2010's data corrected by underreport and adjusted by direct method were evaluated by sex according to age, region of residence, racel skin color, education and conjugal situation. Results: The standardized mortality coefficient of external causes is higher among men (178 per thousand inhabitants) than among women (24 per thousand inhabitants), being higher among young men (20 to 29 years old) in all regions and decreasing with aging. The mortality rate reaches almost nine times higher among men comparably to women, being higher in North and Northeast regions. The death incidence by external causes is higher among men (36.4\%) than among women (10.9\%), meaning $170 \%$ more risk for men. The risk is also higher among the youngest: 6.00 for men and 7.36 for women. The main kind of death by external causes among men is aggressions, followed by transport accidents, the opposite of women. Conclusions: Besides sex, age is the more important predictive factor of precocious death by external causes, pointing the need of many and various sectors in order to construct new identities of non violence.

Key words Men's health, Mortality, External causes, Gender, Brazil
\end{abstract}




\section{Introduction}

Inequality and gender are interrelated issues. During the last century, the feminist movement began to use the expression gender to denounce the inadequacy of existing explanations for inequalities between women and men ${ }^{1}$. In this sense, explanations arising from differences between the sexes may be released from a biological determinism and expand the discussion, locating it in the context of the social organization of the relationship between the sexes. Starting from the last decades of the $20^{\text {th }}$ century, the field of health has progressively incorporated the perspective of gender, aiming to understand the relations established between men and women in society and their repercussions on state of health, sickness and death, as well as access to and use of health services ${ }^{2}$. In this way, gender, used as an analytical category, may support the development of explanatory hypotheses for differences in mortality and morbidity profiles, including external causes, by sex.

Within Brazil, external causes (accidents and violence) have been the group which most reveals the inequality between men and women in the adult population aged 20 to $59^{3}$. While there has been a fall in these rates over the last decade, the reduction is still small (7\%) and gives the country a differentiated international mortality pattern, as has been illustrated by Abouzhar et $\mathrm{al}^{4}{ }^{4}$, challenging various sectors to reflect on and resolve the complexity of this phenomenon.

For over more than a decade, the literature ${ }^{5-7}$ has drawn particular attention to more aggressive and risky behavior among men, which may explain the higher frequency of external cause deaths compared to women. On the other hand, if Bourdieu's $s^{8}$ considerations on symbolic violence are considered, women may be the target of male domination, without them being recognized as victims of violence9. It is also true that the understanding of differential gender models is fundamental for drawing up strategies aimed at reducing this inequality and the rate of external cause deaths in general.

In this sense, this article estimates the ratios of external cause mortality rates, in particular due to violence and suicide, within Brazilian states and evaluates the risk of death by sociodemographic characteristics, from the relational perspective of gender.

\section{Methods}

The data were obtained from the Mortality Information System (SIM) of the Secretariat of Health Vigilance of the Ministry of Health, for a total of 241,276 male deaths and 112,386 female deaths during the year 2010. Due to the territorial extent of Brazil, the investigation of causes of deaths and active search, there is a delay in concluding the national database, varying from 2 to 3 years, considered internationally as one of the most rapid.

In 2010, the estimated coverage of deaths occurring in Brazil was $94.2 \%$, in such a way that gross data were corrected using factors from the study on active death searches ${ }^{10}$ by state, sex and age group ${ }^{11}$.

The basic cause of death was cited in accordance with the chapters of the International Classification of Diseases - ICD-10 ${ }^{12}$, with chapter XX - external causes being the focus of the study.

The direct method was used for standardizing mortality rates by age, taking the average of the male and female population of 2010 by age decade group (20 to 59 years of age) as a standard. The crude coefficients were calculated (by age group and total), standardized by age according to place of residence (state, regions and country). In addition, the ratio between mortality coefficients between men and women was also calculated.

The dependent variable, external causes, was split into a yes or a no. The Independent variables were: age (50-59, 40-49, 30-39 and 20-29 years old), region of residence (Southeast, South, Center-West, Northeast and North), race/, (black, yellow, white, mixed and indigenous), educational level ( $\geq 8$ and $<8$ years of study) and stable marital status (yes and no), arranged by decreasing order of the currents. Gross probability ratios for external cause death were calculated by sex, separately for each independent variable, using a Poisson regression model and significance level ( $p$ ) for a trend test. Probability ratios adjusted for all of the variables were also calculated using a Poisson regression with a $95 \%$ confidence interval. The principal types of deaths were identified, according to ICD-10 groupings. In order to differentiate cases of violence, the specific mortality coefficients were calculated for violence and for suicides ${ }^{13}$. 


\section{Results}

Table 1 shows that the standardized external cause mortality coefficient is much greater among men (183 per 100,000 inhabitants) than among women (23 per 100,000 inhabitants). The coefficients are higher among younger men (20 to 29 years old) in every region and diminish with age. Among women, this pattern only occurs in the Center-West region. In the other regions, the coefficients diminish between the first age group (20 to 29 years old) and the second (30 to 39 years old), rising again in the third (40 to 49 years old) or fourth (50 to 59 years old), to reach values very close to those of younger women, with the exception of the South region, which basically stabilizes the fall from the age of 30 onwards.

The difference between the sexes is clearly identified in the external cause mortality ratio, which reaches 7.5 times more among men than among women. We may also add to this the re-

Table 1. Adjusted mortality coefficient (per 100,000 inhabitants) and mortality risk ratio due to external causes, according to place of residence and sex. Brazil, 2010.

\begin{tabular}{|c|c|c|c|c|c|c|c|c|c|c|c|}
\hline \multirow{4}{*}{ Location } & \multicolumn{5}{|c|}{ Men } & \multicolumn{5}{|c|}{ Women } & \multirow{4}{*}{$\begin{array}{c}\text { Risk } \\
\text { ratio* }^{*}\end{array}$} \\
\hline & \multicolumn{4}{|c|}{ Crude } & \multirow[t]{2}{*}{ Adjusted } & \multicolumn{4}{|c|}{ Crude } & \multirow[t]{2}{*}{ Adjusted } & \\
\hline & \multicolumn{4}{|c|}{ Age (years) } & & \multicolumn{4}{|c|}{ Age (years) } & & \\
\hline & $20-29$ & $30-39$ & $40-49$ & 50-59 & & $20-29$ & $30-39$ & $40-49$ & $0-59$ & & \\
\hline North & 294 & 218 & 194 & 172 & 229 & 28 & 24 & 24 & 27 & 26 & 8.9 \\
\hline $\mathrm{RO}$ & 272 & 230 & 237 & 207 & 241 & 27 & 37 & 33 & 61 & 37 & 6.5 \\
\hline $\mathrm{AC}$ & 158 & 187 & 120 & 139 & 154 & 32 & 24 & 11 & 17 & 22 & 6.9 \\
\hline $\mathrm{AM}$ & 262 & 184 & 158 & 147 & 197 & 21 & 19 & 20 & 25 & 21 & 9.4 \\
\hline $\mathrm{RR}$ & 243 & 235 & 203 & 154 & 216 & 41 & 45 & 49 & 43 & 44 & 4.9 \\
\hline $\mathrm{PA}$ & 333 & 239 & 202 & 170 & 249 & 29 & 23 & 23 & 18 & 24 & 10.3 \\
\hline $\mathrm{AP}$ & 294 & 211 & 179 & 208 & 230 & 21 & 12 & 28 & 26 & 21 & 11.1 \\
\hline TO & 269 & 183 & 213 & 203 & 221 & 35 & 30 & 26 & 35 & 31 & 7.0 \\
\hline Northeast & 308 & 223 & 174 & 156 & 227 & 28 & 24 & 24 & 27 & 26 & 8.8 \\
\hline MA & 285 & 204 & 158 & 138 & 208 & 29 & 28 & 23 & 27 & 27 & 7.7 \\
\hline PI & 217 & 177 & 140 & 142 & 175 & 24 & 24 & 20 & 28 & 24 & 7.3 \\
\hline $\mathrm{CE}$ & 301 & 238 & 189 & 189 & 238 & 26 & 20 & 27 & 31 & 25 & 9.4 \\
\hline $\mathrm{RN}$ & 228 & 188 & 167 & 140 & 188 & 28 & 26 & 21 & 26 & 26 & 7.3 \\
\hline $\mathrm{PB}$ & 307 & 221 & 158 & 147 & 221 & 25 & 19 & 23 & 24 & 23 & 9.7 \\
\hline $\mathrm{PE}$ & 306 & 216 & 179 & 155 & 226 & 27 & 23 & 26 & 26 & 25 & 8.9 \\
\hline $\mathrm{AL}$ & 458 & 303 & 239 & 176 & 316 & 32 & 32 & 24 & 22 & 29 & 11.1 \\
\hline SE & 283 & 248 & 199 & 176 & 235 & 29 & 27 & 25 & 35 & 29 & 8.2 \\
\hline $\mathrm{BA}$ & 334 & 225 & 163 & 145 & 232 & 28 & 24 & 24 & 26 & 26 & 9.0 \\
\hline Southeast & 172 & 137 & 120 & 117 & 140 & 21 & 19 & 21 & 22 & 21 & 6.8 \\
\hline MG & 193 & 151 & 129 & 123 & 155 & 25 & 25 & 25 & 25 & 25 & 6.2 \\
\hline ES & 305 & 223 & 199 & 185 & 237 & 35 & 36 & 33 & 30 & 34 & 7.0 \\
\hline RJ & 228 & 153 & 126 & 118 & 165 & 22 & 17 & 23 & 23 & 21 & 7.8 \\
\hline SP & 130 & 117 & 106 & 107 & 117 & 18 & 15 & 17 & 19 & 17 & 6.9 \\
\hline South & 197 & 160 & 136 & 119 & 159 & 27 & 23 & 24 & 23 & 24 & 6.5 \\
\hline PR & 258 & 193 & 150 & 134 & 194 & 33 & 25 & 25 & 24 & 27 & 7.1 \\
\hline SC & 148 & 140 & 127 & 113 & 135 & 26 & 23 & 26 & 27 & 25 & 5.3 \\
\hline RS & 168 & 139 & 129 & 109 & 141 & 21 & 21 & 21 & 21 & 21 & 6.7 \\
\hline Center-West & 246 & 184 & 160 & 155 & 193 & 31 & 30 & 29 & 27 & 29 & 6.6 \\
\hline MS & 220 & 169 & 168 & 149 & 182 & 32 & 29 & 28 & 24 & 29 & 6.3 \\
\hline MT & 274 & 220 & 202 & 199 & 229 & 32 & 40 & 35 & 27 & 34 & 6.7 \\
\hline GO & 273 & 194 & 151 & 152 & 202 & 35 & 30 & 29 & 30 & 31 & 6.4 \\
\hline DF & 178 & 135 & 120 & 109 & 141 & 21 & 18 & 21 & 24 & 21 & 6.7 \\
\hline Brazil & 230 & 173 & 144 & 132 & 178 & 25 & 22 & 23 & 24 & 24 & 7.5 \\
\hline
\end{tabular}

"Adjusted coefficient for men/adjusted coefficient for women. 
gional difference, for which the ratio reaches 9.1 in the North and 8.9 in the Northeast versus 6.5 in the South, 6.6 in the Center-West and 6.8 in the Southeast. Pará and Amapá stand out in the North region and Alagoas in the Northeast region, while the lowest ratio (4.9) was observed in Roraima.

The standardization of mortality rates by age (crude rate for each state applied to the same population age structure) allows places of residence to be compared. The Southeast region notably presents the lowest rates for both sexes. The highest external cause mortality rates for men are observed, in decreasing order, in the North $(63 \%$ higher than the Southeast), Northeast (62\%), Center-West (38\%) and South (13\%) regions. Among women, there is an inversion, with the Center-West region (44\% higher than the Southeast) presenting the highest coefficient, followed by the North and Northeast (26\%) and South (19\%). Notable among states is Roraima, with the highest standardized rates for both men and women.
Table 2 shows that the incidence of external cause deaths is much higher among men than among women (36.4\% versus $10.9 \%)$, representing a risk of early death due to external causes for men almost five times higher than among women.

The association with sociodemographic variables shows similar behavior between the sexes, i.e. the risk is greater among younger people (6.3 among men and 8.3 among women), is lowest among residents of the Southeast region (for men it is higher among residents of the North region and for women in the Center-West region), it is higher among those of mixed and indigenous race/color, individuals, with a higher education level and unstable marital status.

However, after an adjustment for all of the variables, it was found that age maintains an inverse gradient (higher among women, 7.36 versus $6.00)$, but that there is a reduction in differences by region of residence (slightly higher in the South and North region for men and lower in the Southeast and North region for women), which is higher for mixed race men and straight and in-

Table 2. Incidence (\%), Incidence coefficient, gross (RI) and adjusted (RIaj) with a 95\% confidence interval (IC95\%), of deaths due to external causes pursuant to sociodemographic and sex variables. Brazil, 2010.

\begin{tabular}{|c|c|c|c|c|c|c|c|c|}
\hline & \multicolumn{4}{|c|}{ Male } & \multicolumn{4}{|c|}{ Female } \\
\hline & $\%$ & PR & PRaj & IC95\% & $\%$ & PR & PRaj & IC95\% \\
\hline Total & 36.4 & 4.7 & & & 10.9 & 1 & & \\
\hline \multicolumn{9}{|c|}{ Age (years) } \\
\hline $50-59$ & 12.2 & 1 & 1 & & 4.2 & 1 & 1 & \\
\hline $40-49$ & 26.9 & 2.2 & 2.15 & $2.09-2.21$ & 8.8 & 2.1 & 2.01 & $1.88-2.15$ \\
\hline $30-39$ & 53.7 & 4.4 & 4.27 & $4.16-4.38$ & 18.4 & 4.4 & 4.01 & $3.76-4.28$ \\
\hline $20-29$ & 77.5 & $6.3^{*}$ & 6.00 & $5.86-6.16$ & 34.9 & $8.3^{*}$ & 7.36 & $6.92-7.83$ \\
\hline \multicolumn{9}{|c|}{ Region of residence } \\
\hline SE & 29.2 & 1 & 1 & & 9.2 & 1 & 1 & \\
\hline$S$ & 34.3 & 1.2 & 1.19 & $1.17-1.21$ & 11.5 & 1.2 & 1.24 & $1.17-1.31$ \\
\hline $\mathrm{CO}$ & 41.1 & 1.4 & 1.10 & $1.08-1.13$ & 14.2 & 1.5 & 1.22 & $1.14-1.32$ \\
\hline $\mathrm{NE}$ & 43.9 & 1.5 & 1.15 & $1.13-1.16$ & 11.9 & 1.3 & 1.14 & $1.08-1.20$ \\
\hline $\mathrm{N}$ & 47.6 & $1.6^{*}$ & 1.18 & $1.16-1.21$ & 12.9 & $1.4^{*}$ & 1.00 & $0.93-1.08$ \\
\hline \multicolumn{9}{|c|}{ Race/Colour } \\
\hline Black & 28.5 & 1 & 1 & & 6.5 & 1 & 1 & \\
\hline Yellow & 23.2 & 0.8 & 0.90 & $0.77-1.06$ & 10.1 & 1.5 & 1.37 & $0.96-1.96$ \\
\hline White & 29.8 & 1.0 & 1.08 & $1.05-1.11$ & 10.4 & 1.6 & 1.47 & $1.35-1.61$ \\
\hline Mixed & 44.8 & 1.6 & 1.28 & $1.25-1.31$ & 12.9 & 2.0 & 1.66 & $1.52-1.82$ \\
\hline Native & 42.5 & $1.5^{*}$ & 1.09 & $0.96-1.24$ & 15.1 & $2.3^{*}$ & 1.66 & $1.13-2.44$ \\
\hline \multicolumn{9}{|c|}{ Study (years) } \\
\hline$\leq 8$ & 28.6 & 1 & 1 & & 6.7 & 1 & 1 & \\
\hline$>8$ & 39.4 & $1.4^{*}$ & 1.20 & $1.18-1.22$ & 12.4 & $1.8^{*}$ & 1.44 & $1.37-1.51$ \\
\hline \multicolumn{9}{|c|}{ Stable civil status } \\
\hline Yes & 23.5 & 1 & 1 & & 8.0 & 1 & 1 & \\
\hline No & 43.1 & $1.8^{*}$ & 1.03 & $1.02-1.05$ & 12.6 & $1.6^{*}$ & 1.17 & $1.12-1.23$ \\
\hline
\end{tabular}

${ }^{*} \mathrm{p}<0.05$. 
digenous women (with it notable that in general, there is an overlap of confidence intervals), there is a reduction of risk by increasing educational level (men with a higher educational level have a risk 20\% higher and women a risk $44 \%$ higher than the respective categories with a lower educational level) and for unstable marital status (men $3 \%$ and women $17 \%$ ).

Adding sex to the adjusted regression model, the risk among men falls to 2.7. This means that maintaining all of the other variables equal, the risk of early death among men due to external causes is $170 \%$ higher than for women.

The principal types of external cause deaths (Figure 1) among men are those due to violence, followed by land-based transport accidents (including all types), which is the opposite to women. The proportional distribution by type of death relating to external causes shows that more deaths among women are due to suicide than among men.

Violence accounts for almost 80 deaths per 100,000 men (Figure 2), a rate 12 times higher than among women. Coefficients fall gradually with increasing age in every region of Brazil for both sexes. Rates higher than 115 per 100,000 men were observed in the North and Northeast regions and lower than 60 in the Southeast and South of the country. Among women the rate varied from 5.0 in the Southeast to 8.5 in the North. The high coefficients for younger men in the North and Northeast were notable, with these as high as 18 times those for younger women in the same regions.

With regard to rates for suicides (Figure 3), within Brazil 10.7 men and 3.4 women died per 100,000 inhabitants. In total, among men, coefficients fell gradually with increasing age, but increased among women. The highest rates were observed in the Center-West (16.4 among men and 4.3 among women) and the lowest in the North for men (10.7) and in the North and Southeast for women (3.1). The greatest differences occurred in the Southeast (20 to 29 years old) and Northeast regions (30 to 39 years old) with men registering coefficients almost 8 times higher than women.

\section{Discussion}

This study showed that the difference between the sexes is clearly identified in the mortality ratio, which estimated that for each woman, almost 8 men die from external causes in Brazil. This difference may be understood better on the basis of the inequalities between men and women, from a perspective of cultural models of gender. According to Souza ${ }^{14}$, men expose themselves more to situations of accidents and violence on account of their conduct specific to contemporary society, which reaffirmed masculinity, symbolizing greater power and requiring greater virility and aggressiveness, paradoxically making them more vulnerable to events with a risk of early death due to avoidable escalations.

We should highlight that during the last period between censuses, women registered an increase in crude rates of external cause deaths, as well as for neoplasms ${ }^{15}$.

In addition to the differences between the sexes, we may also observe a regional difference,

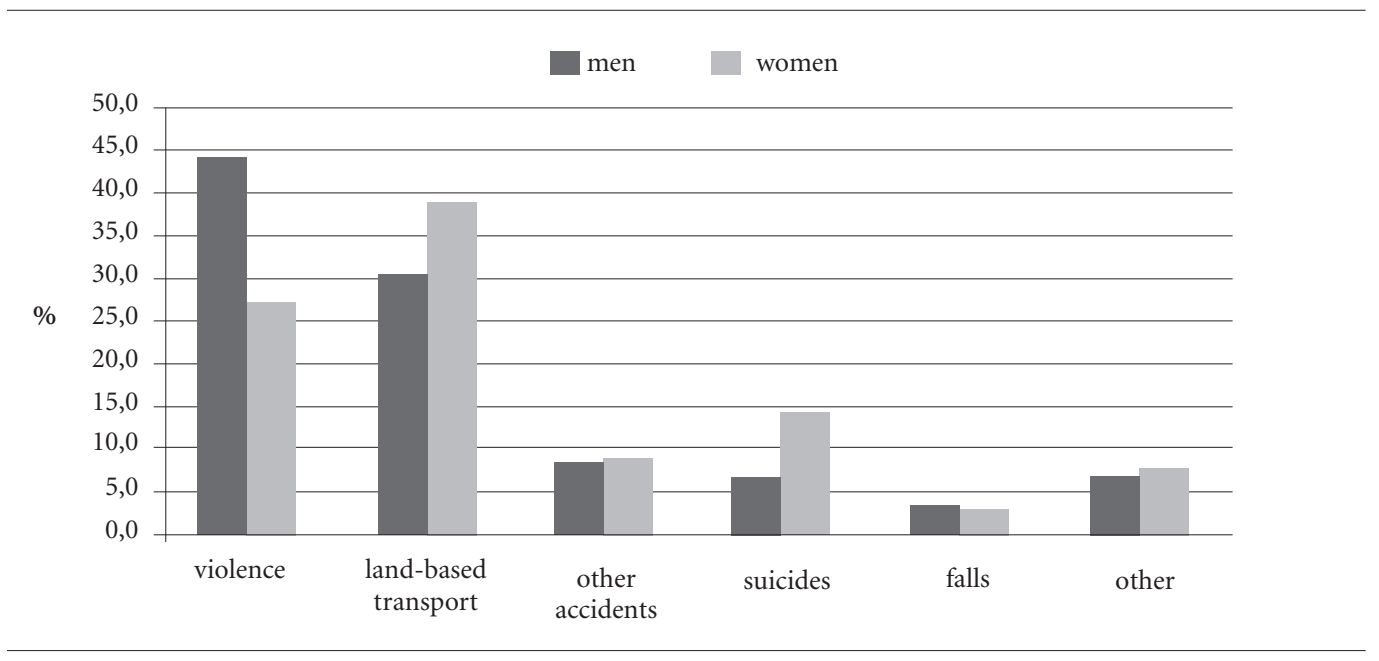

Figure 1. Distribution (\%) of deaths by type of external cause and by sex, Brazil, 2010. 
with the North and Center-West regions the most affected for men, in decreasing order; the least affected was the Southeast for both sexes. This pattern has been maintained over the last two decades, as identified in the study on mortality due to violence and accidents among young people aged 15 to 29 within Brazil ${ }^{16}$, which highlighted that for the period 1990-2005, the Center-West took first place for external cause mortality, with the North region registering a gradual increase in this rate. Conversely, the Southeast region was the only one which registered a decline, principally influenced by the state of São Paulo, which continues to maintain its position.

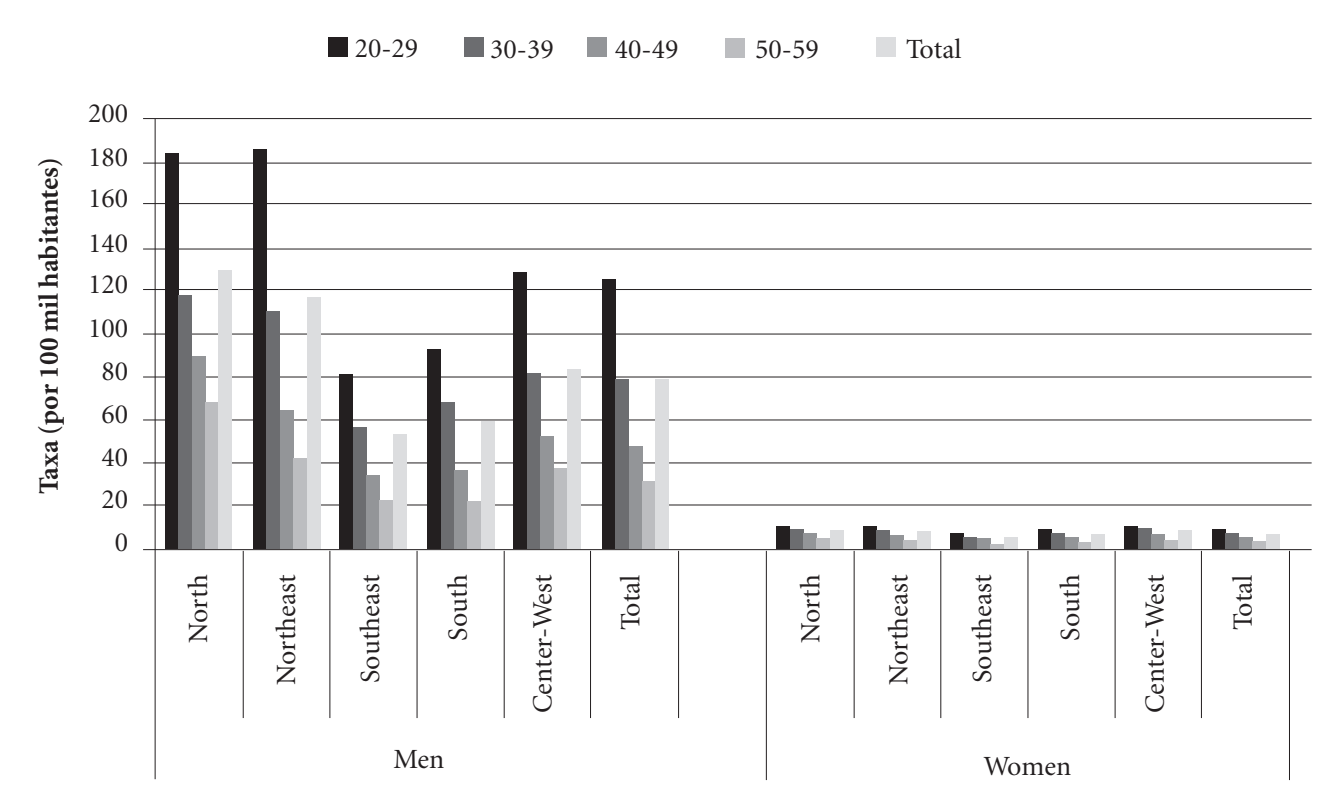

Figure 2. Coefficient (per 100,000 inhabitants) for violent death by age range, region of residence for men and women. Brazil, 2010.

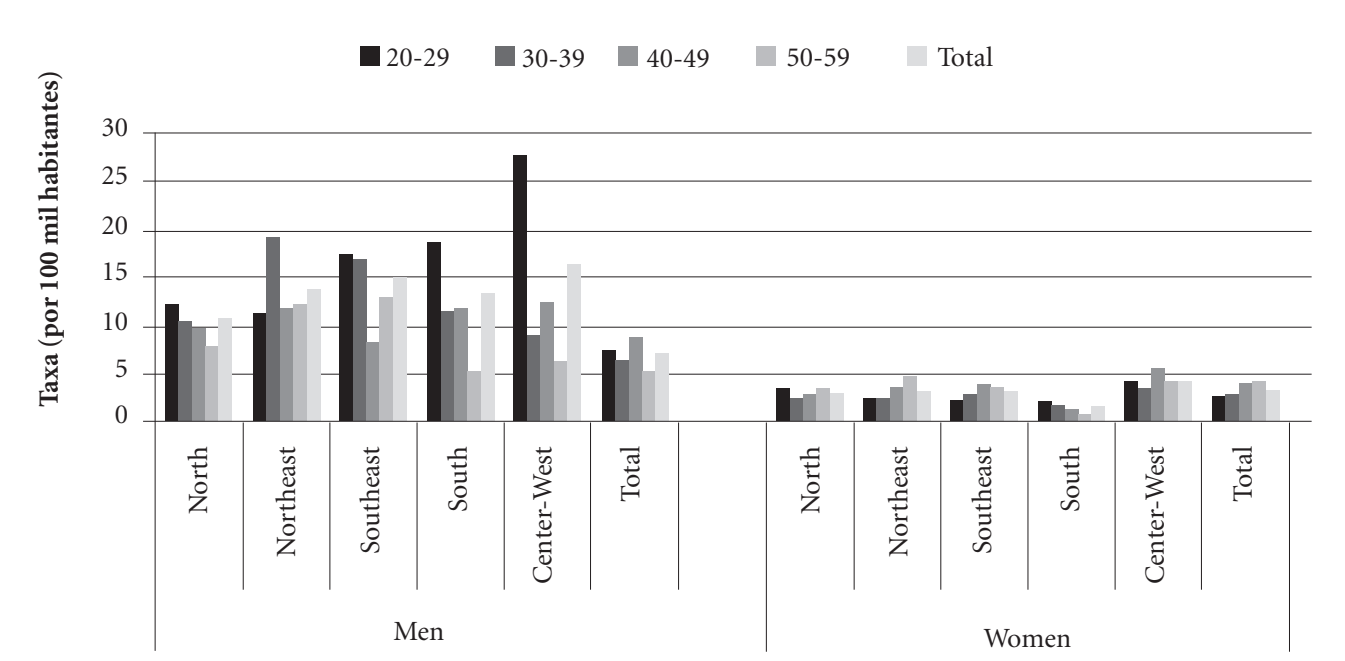

Figure 3. Coefficient (per 100,000 inhabitants) of death through suicide by age range, region of residence for men and women. Brazil, 2010. 
The Poisson regression, adjusted for all of the studied variables (sex, age, region of residence, race/color, educational level and marital status), shows that men have a risk of early death due to external causes 2.7 times higher than that of women.

According to Victora et al. ${ }^{17}$, these types of deaths are among the health problems with unacceptably high levels and since the 1980s, have appeared among the principal causes of mortality, being aggravated by gender inequality and challenging various sectors to resolve this phenomenon ${ }^{18}$.

In general, the data show that the principal risk factor for both sexes is age. Considering that national and international studies highlight that external cause mortality greatly affects young males living in large urban centers in areas with a juxtaposition of social disadvantages, it is important to consider indicators such as community and criminal violence, the presence of drug trafficking and other illegal activities as important factors for understanding the differentials between the sexes, by different age group ${ }^{19,20}$.

When the data for women are analyzed, we observe that those with a higher educational level and unstable marital status run a greater risk than men in the same categories, as well as white and mixed race women.

This study highlights the fact that mixed race race/color men have a higher probability of death due to external causes (28\%) than black, yellow and indigenous as well as white (8\%) men. A study carried out in Salvador (State of Bahia) of external cause deaths which occurred between 1998 and 2003 showed that the mixed race population loses more potential years of life (13.0 times more for men and 6.2 for women) due to external causes than the white population ${ }^{21}$, as well as black men (3.0 times more) These data are partially corroborated by the data presented by Soares Filho ${ }^{22}$, in a study on deaths due to homicide occurring between 2000 and 2009, showing a greater (and growing) risk of death of the black population (black and mixed race) than the white one, regardless of educational level. We highlight that the cited studies exclude the indigenous and yellow populations due to the low occurrence of the evaluated event in these categories.

With regard to the region of residence, the risk of early death due to external causes is equal in the South (19\% higher) and in the North (18\% higher) and slightly lower in the Northeast (13\%) and Center-West (10\%), in relation to the Southeast region.
Andrade et al. ${ }^{23}$, who evaluated deaths due to homicide among men aged 15 to 29 in the state of Paraná between 2002 and 2004, identified an association with social inequality (as expressed by the Gini index) and not with poverty, noting that unequal access to goods and services determines the state of violence. This is corroborated by Peres et al. ${ }^{24}$, who maintain the hypothesis that demographic changes, economic acceleration, investments and social policies and changes in public security policies acted jointly to reduce the mortality rate due to homicide in the municipality of São Paulo between 1996 and 2008. An ecological study of death due to homicide among men aged 20 to 39, during the period from 1999 to 2010 , indicates an increase in risks in municipalities with higher population levels, fertility, income and urbanization inequality and lower literacy levels ${ }^{25}$.

Specifically in relation to suicide, we observe that despite the fact that the percentage of deaths due to suicide among women is higher, rates are lower than among men, who in turn show a higher proportion of deaths due to violence. When Lovisi et al. ${ }^{26}$ discuss higher suicide rates among men than among women, they present International studies which reflect gender issues linked to the propensity the suicide, highlighting that women have a greater propensity to suicide but that men are often more successful in their attempts, suggesting that they use more lethal methods, since the male intention to die is stronger. Also according to the cited authors, the lower mortality rate due to suicide among women may be associated with: the low frequency of alcoholism, stronger religious beliefs, social support and seeking help in the face of mental disorders and suicidal thoughts.

Souza $^{14}$ had already drawn attention to the growth in external cause deaths among young middle and upper class people, in so far as the use of weapons (deaths due to violence) and cars (deaths due to accidents) are symbols and representations of force: power of submission/control of life and power of movement /speed/freedom, which became evident in this study, in which a higher educational level acts as a risk factor (the probability of external cause death is $22 \%$ higher, compared to the group with a lower educational level), as well as unstable marital status (risk 3\% higher).

Global data show that in 2011, external causes accounted for approximately 3.5 million deaths among individuals aged between 15 and 69, corresponding to $15.4 \%$ of global mortality and to 
73 deaths per 100,000 inhabitants ${ }^{27}$. The same data further reveal that the proportion of deaths due to these causes is almost double among men (18.8\% in men and $10.3 \%$ in women) and that the mortality rate is approximately three times higher for this sex (105.6 in men and 39.8 in women). In comparing the values for the years 2000 and 2011, we observe that external cause mortality has fallen, although the difference between the sexes has increased ${ }^{26}$.

Within Brazil, external cause deaths are around $21.6 \%$ of total deaths, among individuals aged 15 to 69 of both sexes, albeit being three times more frequent among men $(28.6 \%$ among men and $8.3 \%$ among women), affecting 159 men and 23 women for every 100,000 inhabitants, according to 2010 data $^{28}$. These values are close to those of African countries, albeit with greater inequality: approximately 160 deaths among men and 59 among women for every 100,000 inhabitants $^{27}$.

However, violent situations which do not result in death principally affect women, with men as the principal aggressors ${ }^{29}$.

Within this context, the National Policy of Full Attention to Men's Health (PNAISH) introduced in 2009 by the Ministry of Health ${ }^{18,30}$ with the objective of promoting health actions, which expanded the comprehension of the male reality and quality access to men aged between 20 and 59 in their various contexts, to the fulltime health assistance services of the SUS [Single Health System] Network, has focused some of its principal strategies on the younger population, whose risk of death is six times higher than that of men aged 50 to 59 , noting the strength of association between cause of death and age ( 4.27 between the ages of 30 and 39 and 2.15 between the ages of 40 and 49 ).

These strategies are above all focused on the planning and execution of educational actions within the health territories intended for the reconfiguration of structures and practices of Basic Healthcare, principally in the Family Health Strategy (ESF), with a special focus on awareness raising and capacity building among workers within health teams, with regard to the prevention of violence and accidents, as well as actions for identifying, receiving and forwarding these situations, involving men in the articulation within a network on the basis of the design of lines of care with other levels of media attention and high complexity, gradually contributing to the reduction of morbimortality due to these affronts and in order to change paradigms in the sphere of care and enhancement of life as being the exclusive preserve of women, so that it is also available to, cultivated and practiced by men in all age groups.

This study was realized with secondary data, obtained from the Mortality Information System, which did not permit an analysis of causality, but simply of association. It nevertheless reinforces the findings of the literature and highlights important differences between the sexes.

In any event, the discussion of the predominance of male external deaths relative to female ones needs to be expanded with an interdisciplinary analysis, which contemplates an analysis in greater depth of the singular nature of hegemonic models of masculinity, which are still present, active and reinforced within the collective social imagination. On the basis of the understanding of these models, public policies will have better contributions for understanding this phenomenon in which men both die and kill because, in affirming their virile condition as an inalienable choice of what it means to be a man, they find themselves living under exacerbated tension and restrictions, characterized by both physical and symbolic violence ${ }^{8}$.

In addition to sex, age is the most important predictive factor of early external cause mortality, with the differences disappearing between the categories of the other variables after adjustment for the majority of them. This requires multi-sector actions, centered on locations of collective existence of men, especially during the formation of their beliefs and values (school pupils, adolescents), in order to resist this drastic loss which the country has been experienced and which runs the risk of increasing, if new values are not established: deconstructing the current hegemonic patterns of virility and aggressiveness, creating new non-violent identities, permitting the flow of emotions and expanding the emotional approximation between men and women. 


\section{Collaborations}

EC Moura contributed in conception and planning, analysis and interpretation of data; R Gomes and MT Couto in analysis and interpretation of data. ACM Neves and W Santos in elaboration of the draft. E Schwarz contributed in approval of the final version of the manuscript.

\section{References}

1. Scott J. Gênero: uma categoria útil de análise histórica. Educação e Realidade 1990; 16(2):5-22.

2. Barata RB. Como e por que as desigualdades sociais fazem mal à saúde. Rio de Janeiro: Ed. Fiocruz; 2009.

3. Moura EC. Perfil da situação de saúde do homem no Brasil. Rio de Janeiro: Editora Fiocruz; 2012.

4. Abouzhar C, Mikkelsen L, Rampatige R, Lopez A. Mortality statistics: a tool to enhance understanding and improve quality. Queensland: University of Queensland; 2010.

5. Gomes R. A dimensão simbólica da violência de gênero: uma discussão introdutória. Athenea Digit 2008; 14(2):237-243.

6. Greig A. Political connections: men, gender and violence. In: United Nations Publications. Partners in Change: Working with Men to End Gender-based Violence. Santo Domingo: Instraw; 2002. p. 10-32.

7. Minayo MCS. Seis características das mortes violentas no Brasil. Rev Brasileira de Estudos de População 2009; 26(1):135-140.

8. Bourdieu P. A Dominação Masculina. Rio de Janeiro: Bertrand Brasil; 1999.

9. Gomes R. Sexualidade masculina, gênero e saúde. Rio de Janeiro: Editora Fiocruz. 2008.

10. Szwarcwald CL, Morais Neto OL, Frias PF, Souza Junior PRB, Cortez-Escalante JJ, Lima RB, Viola RC. Busca ativa de óbitos e nascimentos no Nordeste e na Amazônia Legal: estimação das coberturas do SIM e Sinasc nos municípios brasileiros. In: Brasil. Ministério da Saúde (MS). Saúde Brasil 2010: uma análise da situação de saúde e de evidências selecionadas de impacto de ações de vigilância em saúde. Brasília: MS; 2011. p. 99-116.

11. Morais Filho OL, Moura EC, Cortez-Escalante JJ. Como morrem os brasileiros: tendências e desigualdades nas regiões, unidades federadas e nas categorias de raça-cor nos anos de 2000 a 2010. In: Brasil. Ministério da Saúde (MS). Saúde Brasil 2011: uma análise da situação de saúde e a vigilância da saúde da mulher. Brasília: MS; 2012. p.105-163.

12. World Health Organization. Injuries and violence: the facts. Geneva: WHO; 2010.

13. Farias N, Souza JMP, Laurenti R, Alencar SM. Mortalidade cardiovascular por sexo e faixa etária em São Paulo, Brasil: 1996 a 1998 e 2003 a 2005. Arq Bras Cardiol 2009; 93(5):498-505.

14. Souza ER. Masculinidade e violência no Brasil: contribuições para a reflexão no campo da saúde. Cien Saude Colet 2005; 10(1):59-70.

15. Garcia LP, Freitas LRS. Mortalidade feminina no Brasil: evolução no período de 2000 a 2010. In: Brasil. Ministério da Saúde (MS). Saúde Brasil 2011: uma análise da situação de saúde e a vigilância da saúde da mulher. Brasília: MS; 2012. p.303-328.

16. Souza ER, Minayo MCS. Mortalidade de jovens de 15 a 29 anos por violências e acidentes no Brasil: situação atual, tendências e perspectivas. In: Rede Interagencial de informações para a saúde. Demografia e saúde: contribuição para análise de situação e tendências. Brasília: OPAS; 2009. p. 113-142. 
17. Victora CG, Barreto ML, Leal MC, Monteiro CA, Schmidt MI, Pain J, Bastos FI, Almeida C, Bahia L, Travassos C, Reichenheim M, Barros FC \& the Lancet Brazil Series Working Group. Condições de saúde e inovações nas políticas de saúde no Brasil: o caminho a percorrer. Lancet 2011; 6(Supl. Saúde no Brasil):90-102.

18. Brasil. Ministério da Saúde (MS). Política Nacional de Atenção Integral à Saúde do Homem: princípios e diretrizes. Brasília: MS; 2009.

19. McCall PL, Parker KF, MacDonald JM. The dynamic relationship between homicide rates and social, economic, and political factors from 1970 to 2000 . Social science research 2008; 37(3):721-735.

20. Zaluar A. Integração perversa: pobreza e tráfico de drogas. Rio de Janeiro: Editora FGV; 2004.

21. Araújo EM, Costa MCN, Hogan VK, Mota ELA, Araújo TM, Oliveira NF. Diferenciais de raça/cor da pele em anos potenciais de vida perdidos por causas externas. Rev Saude Publica 2009; 43(3):405-441.

22. Soares Filho AM. Vitimização por homicídios segundo características de raça no Brasil. Rev Saude Publica 2011; 45(4):745-755.

23. Andrade SM, Soares DA, Souza RKT, Matsuo T, Souza HD. Homicídios de homens de quinze a 29 anos e fatores relacionados no estado do Paraná, de 2002 a 2004. Cien Saude Colet 2011; 16(Supl.1):1281-1288.

24. Peres MFT, Almeida JF, Vicentin D, Cerda M, Cardia N, Adorno S. Queda dos homicídios no município de São Paulo: uma análise exploratória de possíveis condicionantes. Rev bras epidemiol 2011; 14(4):709-721.

25. Duarte EC, Garcia LP, Freitas LRS, Mansano NH, Monteiro RA, Ramalho WM. Associação ecológica entre características dos municípios e o risco de homicídios em homens adultos de 20-39 anos de idade no Brasil, 1999-2010. Cien Saude Colet 2012; 17(9):2259-2268.
26. Lovisi GM, Santos AS, Legay L, Abelha L, Valencia E. Análise epidemiológica do suicídio no Brasil entre 1980 e 2006. Rev Bras Psiquiatr 2009; 31(Supl. 2):S86-S93.

27. World Health Organization (WHO). Disease and injury regional estimates: cause specific mortality: regional estimates for 2000-2011. Geneva: WHO; 2013.

28. Brasil. Mortalidade geral e por causas - por local de residência - Brasil. Rio de Janeiro: MS; 2013. [acessado 2013 out 1]. Disponível em: http://tabnet.datasus.gov. br/cgi/tabcgi.exe?sih/cnv/nruf.def Acesso em: outubro de 2013.

29. Gomes DL, Malta DC, Silva MMA, Paiva EA, Moraes Neto AV, Nunes ML, Silva RE, Medeiros AC, Viegas APB, Lima CM. Violência contra mulheres adultas no Brasil: análise das notificações do Sistema de Vigilância de Violências em 2010. In: Brasil. Ministério da Saúde (MS). Saúde Brasil 2011: uma análise da situação de saúde e a vigilância da saúde da mulher. Brasília: MS; 2012. p. 327-344

30. Schwarz E, Gomes R, Couto MT, Moura EC, Carvalho SA, Silva SFC. Política de saúde do homem. Rev Saúde Pública 2012; 46(Supl. 1):108-116.

Article submitted 03/06/2014

Approved 14/08/2014

Final version submitted 16/08/2014 


\section{ERRATUM}

p. 779, which reads:

${ }^{3}$ Instituto Brasileiro de Ecologia Humana, Ministério da Saúde.

reads up:

${ }^{3}$ Departamento de Ações Programáticas e Estratégicas, Secretaria de Atenção à Saúde, Ministério da Saúde.

\section{p. 782, which reads:}

Table 2. Incidence (\%), Incidence coefficient, gross (RI) and adjusted (RIaj) with a 95\% confidence interval (IC95\%), of deaths due to external causes pursuant to sociodemographic and sex variables. Brazil, 2010.

reads up:

Table 2. Proportion (\%), proportion rate, crude (PR) and adjusted (PRaj) with a 95\% confidence interval (IC95\%), of deaths due to external causes pursuant to sociodemographic and sex variables. Brazil, 2010. PR PRaj 